\title{
Enhancing business competitiveness of medium-sized food produce retailers through supply chain management
}

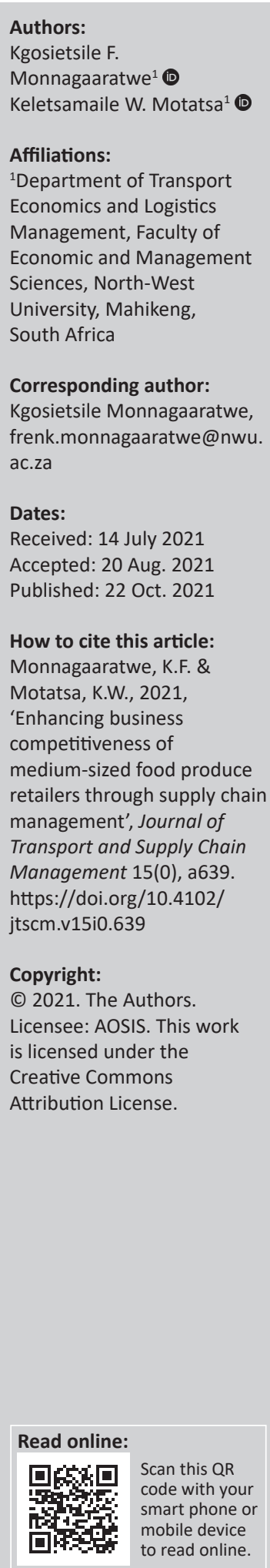

Background: Adoption of supply chain management (SCM) initiatives by businesses has resulted in businesses to follow a customer-centric approach in their operation. SCM initiatives nowadays play a critical role in the success and business competitiveness of organisations in ensuring that the customer requirements are satisfied. The purpose of this study was to explore whether business competitiveness of medium-sized food product retailers in Mahikeng is enhanced through SCM in South Africa. There was no empirical evidence of SCM practices found relating to SCM of medium-sized food product retailers in Mahikeng.

Research objectives: This study explored whether SCM and supply chain collaboration enhance business competitiveness of medium-sized food product retailers in Mahikeng town, South Africa.

Research methodology: A qualitative research method, descriptive design, non-probability sampling strategy were followed to conduct the study. The notes and recorded interviews were transcribed, coded and analysed following thematic data analysis to get to the results.

Results: The study showed that SCM enhances the business competitiveness of medium-sized food product retailers in South Africa. The results revealed that the competitiveness of the retailers is enhanced through good and improved supplier/ customer relationships by sustained continuous flow of goods and services.

Conclusion: This study implicated that competitive advantage and resource-based view theories can be used to explore business competitiveness in South Africa. Implications of the findings indicated that owner/managers will understand the benefits of adopting initiatives of SCM.

Keywords: competitiveness; competitive advantage; supply chain; supply chain management; supply chain collaboration; logistics management; 3PL and medium-sized food product retailers.

\section{Introduction}

Adoption of supply chain management (SCM) initiatives by businesses has been one of the business strategies, which has resulted in businesses to follow customer-centric approach in their operation in order to satisfy customer requirements. Supply chain management nowadays plays a critical role in the success and business competitiveness of organisations in ensuring that the customer requirements are satisfied (Christopher 2011:4). A business competitive environment forces organisations to adopt SCM approaches in order to supply their customers with quality products, instant deliveries and at the right price. This provides businesses with an added competitive advantage over their competitors. Lambert (2014:2) indicated that nowadays individual businesses do not compete as autonomous businesses but rather as supply chains (SC) as a result of a modern paradigm shift in business management.

Mathu and Phetla (2018:1) stated that businesses make use of several initiatives in order to enhance their SCs' performance in order to meet market or customer requirements. Increased competition amongst businesses shows that improving SCs will be amongst the stories that lead in the agenda of retailers and consumer goods organisations that are currently having a focus on centralising their supplies (Klynveld Peat Marwick Goerdeler [KPMG] 2014:5). Furthermore, in a report by KPMG (2014:5), it is reported that food product retailers have to compete on the basis of price because fast-moving consumer goods (FMCGs) suppliers are the same in the categories. In this study, FMCGs suppliers are regarded also as the manufacturers of food products they sell to 
medium-sized food products retailers and medium-sized food products retailers are referred to as general dealers and supermarkets that sell packaged food products.

This study is underpinned by competitive advantage and resource-based view (RBV) theories. Competitive advantage is 'a firm's ability to produce a good or service more efficiently than its competitors, which leader to a greater profit margin, creating a competitive advantage' as proposed by (Porter 1985), whereas the RBV theory is pronounced by Rothaermel (2012:91) as the foundation on which successful organisations will find their prospective competitiveness by developing unique and inimitable competencies which can be tangible or intangible in nature.

The purpose of this study was to establish whether business competitiveness of medium-sized food product retailers in Mahikeng, North-West (NW) province is enhanced through SCM. It was expressed by the Supply Chain Council (SCC 2016) that SCM plays a crucial role in enhancing competitiveness of businesses. 'Competitiveness is the ability of a firm to compete in a market place for goods or services' Pienaar and Vogt (2016:33).

The following section presents theoretical frameworks underpinning this study.

\section{Theoretical frameworks}

This study was underpinned in competitive advantage and RBV theories.

\section{Theory of competitive advantage}

The theory of competitive advantage was proposed by Porter (1985) stating that it holds an idea that it gives businesses a chance to compete and perform greater than competitors. Cost leadership and differentiation are outlined as the main sources of competitive advantage as outlined by the theory (Porter 1985:3). Hatten (2012:11) and Jooste et al. (2012) mentioned:

[T] hat the achievement of any organisation, a small organisation also included, depends amongst others, on identifying a competitive advantage; and before managers can choose a suitable competitive strategy, the competitive advantage must be recognised. (p. 231)

A competitive advantage is a leading edge over competitors and gained by providing customers with a superior value, either by means of lower prices or offering great benefits and improved facilities which may justify higher prices (Pienaar \& Vogt 2016:33). Christopher (2016:4) highlighted that the first source of competitive advantage originated in the capability of the business to distinguish itself from its competitors in a market, and secondly the ability of operating at the lowest cost and hence at an increased profit. In addition, Porter (2008:1) and Scarborough (2011:89) emphasised that competitive advantage is a differentiating factor or a mixture of numerous factors that inspire clients to purchase from a specific business instead of buying from their competitors.
Therefore, the current study's competitive advantage assumption is in line with the idea by Adeniran and Johnston (2012:4090), and Thompson and Martin (2010:785), emphasising that managers must manage processes and valuable resources such as tangible and intangible assets with an effort to establish special set of core capabilities that competitors do not have and will find it difficult to imitate. Having said this, the following section presents the theory of $\mathrm{RBV}$ as the second underpinning theory of this study.

\section{Resource-based view}

The theory of RBV is used in this study as the principal basis to prove the business competitiveness of medium-sized food product retailers in Mahikeng. Rothaermel (2012:91) stated that the organisation-specific RBV explains how organisations can accomplish their competitive advantage and also how to sustain them. The RBV theory is expressed by Rothaermel (2012:91) as the basis on which successful businesses will find their future competitiveness on the development of unique and inimitable competencies which can be tangible or intangible in nature.

\section{Barney, Wright and Ketchen (2001) described that:}

Tangible assets include everything that is physical such as land, buildings, machinery, equipment and capital. Physical resources can be purchased in the market, so they provide advantage to the firms in the long run because soon enough competitors can obtain the same assets. Intangible assets are the ones that cannot be seen nor touched, but can still be owned by the business such as a brand reputation, trademarks and intellectual property. (p. 634)

The framework of RBV assigns resources the key role in assisting businesses to achieve greater organisational performance (Jurevicius 2013). According to Bridoux (2006), the RBV model emphasises that the resources are essential determining factors of the organisation's competitive advantage and performance.

This study will focus on the intangible side of RBV as it aims to establish the attributes of SC competitiveness in mediumsized food product retailers in Mahikeng. The intangible aspect of SC competitiveness of the medium-sized food stores is efficient and timeous delivery, quality of product/ service and right cost. The saving is achieved by sharing third party logistics (3PL) transport service, quality is damage-free goods and timeous delivery. Rothaermel (2012) mentioned that these intangible resources are considered to be the ones that commonly stay inside a business and are the key sources of sustained competitive advantage. Lastly, a significant implication of RBV in this study is on the owner/ managers of medium-sized food product retailers in Mahikeng to concentrate on their key resources and efficiently manage intangible assets and nurture the skill of their employees in relation to the forever changing business competitive environment in order to improve competitive advantage over their competitors. 


\section{Literature review}

The study reviewed literature on SC, SCM, supply chain collaboration (SCC), supplier and customer relationships, logistics management, 3PL, fast moving consumer goods (FMCGs) suppliers and medium-sized food product retailers. The sources consulted for literature were accredited journals articles, SCM and logistics management textbooks and research by professional bodies.

\section{Supply chain and supply chain management}

It is indicated earlier that in today's competitive environment in which businesses operate, the power of effective and efficient SC is required. Christopher (2016) defined SC as a:

[N]etwork of businesses that participate through the linkages of both upstream and downstream in distinct business processes and activities used to create value in the form of products and services in the possession of the end-customer. (p. 13)

Ambe (2010:5) stated that the main capabilities of an organisation depend on its ability to design and manage its SC in order to achieve maximum advantage in a highly competitive market, especially where competitive forces are changing. The report by Price Waterhouse Coopers (PWC 2016:12) indicated that increasing competition reflects that optimising SCs will be amongst top stories in the agenda of retailers and consumer goods businesses are currently focussing on centralising their supplies.

In this study, the type of a SC is described as food products SC. The study by Apaiah, Linnemann and Kooi (2011:21) indicated that the food chain network comprises processes such as production, processing, distribution, consumption and disposal. A sample for the food SC network includes partners such as farmers, processors, distributors, retailers and end-customers (Du Toit et al. 2011:33):

As supply chain is seen as a network of businesses, managing a supply chain (SC) network of role players (relationships) is called supply chain management (SCM) and all business functions must be involved in the management of the supply chain. (Lambert 2014:4)

Harrison, Van Hoek and Skipworth (2014:8) indicated that SCM comprises the planning and controlling of all the processes involved in procurement, conversion, transportation and distribution across SC. Fuzile (2015:4-5) regarded SCM as a management process that is in control of procurement, production and product deliveries to various SC stakeholders in order to create value for the firm through the creation of competitive advantage. The aim of SCM is to create value for customers, competitive advantage and enhance profitability for SC members (Ambe 2010:10). Slack et al. (2017:38) stated that 'the operational capability of SCM follows the main five operations objectives: cost, speed, flexibility, quality and dependability'.

Supply chain collaboration: Boyce, Mano and Kent (2016:1) stated that the evolution of SCM is at a point where collaboration has become a common practice for organisations to achieve shared objectives. American Production and Inventory Control Society (APICS) defines SCC as the establishing working relationships with supplier firms, where two firms act as one (APICS 2013:171). In addition, improved revenue, cost reduction and an increased flexibility to manage demand uncertainties are the tangible benefits of SCC (Mathuramaytha 2011:102).

Supplier relationship management: According to Lambert (2014:54), supplier relationship management (SRM) comprises the establishment of relationships with key suppliers in order to reduce costs, create new products and create value for both parties through mutual commitment with the purpose of establishing long-term collaboration and achieving shared success. In addition, Hoffman (2014:40) defined SRM as a process pursued to get involved with suppliers at a level that describes the firm's priorities and how best these priorities can be achieved. Lambert and Schwieterman (2012) highlighted that:

[S]RM has become an important organisational process as a result of elements such as the competitive pressure, the requirement to consider sustainability and risk and the need to develop closer relationships with key suppliers who will be able to offer the necessary expertise to innovatively develop new products and introduce them to the market. (p. 337)

Customer relationship management: Lambert (2014:10) described customer relationship management (CRM) as a SC business process that provides the structure for how the relationships with customers will be established and maintained. Customer relationship management entails activities and processes with an intention of assisting an organisation to understand, communicate with customers and serve their needs and expectations (Goldenberg 2010:27).

\section{Logistics management}

Council of Supply Management Professionals (CSCMP 2012) defined logistics management as:

[T]hat part of supply chain management that plans, implements and controls the efficient and effective forward and reverse movement and storage of products, services and related information between a point of origin and a point of consumption in order to satisfy customers' requirements. (p. 117)

According to Christopher (2016:2), logistics is a SC business process that strategically manages procurement, movement and storage of materials, parts and finished goods and related information flow through the firm and its marketing channels such that future profit is increased and it costeffectively fulfils customer orders as well (Christopher 2016:2).

Harrison et al. (2014:18) stated that the competitiveness of the SC is supported by logistics management in satisfying the demands of the end-customer by supplying what is required at a time it is needed at a competitive cost. Harrison et al. (2014:18) further indicated that logistics contributes to the 
firm's competitive advantage by offering quality products (offering defect free products, right quantity and correct items), lead time (total time a customer has to wait to receive ordered goods or service) and cost (offering lower cost result a competitive advantage in a market place).

\section{Third party logistics}

Waugh and Luke (2011:337) indicated that organisations in South Africa are geographically apart from each other (suppliers and customers) and this is where logistics is becoming more complex and very expensive and thus they are compelled to look for innovative strategies such as using a 3PL service provider to enhance competitive advantage and increase profits. To successfully compete, businesses are continuously deciding to concentrate on their core activity of competency and expertise and outsource logistics functions they need (Waugh \& Luke 2011:339). According to Hsiao et al. (2010), logistics outsourcing is a business process that entails the usage of external logistics firms to perform functions that were traditionally performed in-house, where the shipper, freight forwarder or logistics service provider contracts with the focal firm or manufacturer to offer services at a specific cost over a certain period.

\section{Transportation and warehousing}

Transportation and warehousing are the most important needs for food products retailers in facilitating the flow of products in their SC. Mathu and Phetla (2018:4) stated that 'transportation role is mostly played by 3PL and they normally supplemented by the retailers' own transport in improving the speed of delivery'. This view supplements the requirement of outsourcing transportation function in this study as most of the suppliers from medium-sized food product retailers are not locally based in Mahikeng as they are in some provinces in South Africa. Szuster (2010:88) highlighted that the transport function is needed in a SC as it links SC members because its service quality affects the SC competitiveness.

Warehousing as one of the essential logistics activities contains the functions that relate to managing the warehouse space needed to keep and maintain stock as goods must be kept for future sales and consumption (Pienaar \& Vogt 2016:15). The study by Udeh and Karaduman (2015:412) showed that for firms to truly concentrate on their core capabilities in the running of a complex warehousing, they need to outsource some processes of SC to an expert organisation in that operation and this includes warehousing function. Kolinska (2016:149) mentioned that outsourcing warehouse space has an effect of logistics cost savings and enhance SC flexibility as well as attractive pricing services provided by the entire SC network.

\section{Fast moving consumer goods suppliers in South Africa}

Fast moving consumer goods (FMCGs) suppliers in this study are also regarded as the manufacturers of food products that are sold to medium-sized food products retailers. In addition, FMCGs according to KPMG (2014:1) and (Industry Today 2020) are regarded as 'low priced fastmoving items with a short shelf-life and are frequently bought on every day by consumers'. Biz Community (2020) described South African suppliers of processed products as food and beverage companies, healthcare and personal care product firms and suppliers of perishables such as meat, dairy, vegetables and poultry products.

Accenture report compiled by Pinder et al. (2017:8) revealed that 'food products retailers and manufacturers (suppliers) have a competitive challenge from their rivals because of new formats, private labels and new brands on their shelves'.

The following section presents a brief discussion on mediumsized food product retailers in South Africa

\section{Medium-sized food product retailers in South Africa}

The Wholesale and Retail Sector Education and Training Authority (W\&R Seta 2011) described that:

[S]mall or medium-sized independent food products retailers as organisations are privately owned and do not belong to larger grocery retail chains and they include food and non-food products retailers such as cash and carry having both wholesale and supermarket offering. (p. 2)

Das Nair and Chisoro (2015:2) stated that small or medium independent retailers target low-income customers and they are a means through which small suppliers can penetrate the SC. The South African small or medium-sized food product retailers who focus on product-related elements such as quality, product variety and best brands in the market provision as their major competitive factors tend to survive and develop (Badenhorst-Weiss, Cilliers \& Eicker 2014).

In a report by KPMG (2014:5), it is indicated that food product retailers have to compete on the basis of price because FMCGs suppliers are the same in the categories. In addition, The Product Market Accusation (PMA 2017) research report stated that the study by Euromonitor International highlighted that the South African grocery retail business environment is extremely competitive with many various retailers who concentrate on price war, competing for prime store locations, training staff, modernising their store and provide dedicated product categories.

\section{Problem statement}

The Product Market Accusation (PMA 2017) research report stated in the study by Euromonitor International highlighted that the South African food products retail business environment is extremely competitive with many various retailers who concentrate on price war, competing for prime store locations, training staff, modernising their store and provide dedicated product categories. The problem statement 
of this research was to establish how SCM drives the business competitiveness of medium-sized food product retailers in Mahikeng. There is no trace of empirical evidence that explains SCM of Mahikeng medium-sized food product retailers, hence this current study submits to discover ways in closing this gap within the broad concepts of SCM-related literature.

Therefore, the research questions of this study are as follows:

'How does supply chain management affects the business competitiveness of medium-sized food product retailers within Mahikeng, North-West province?'

'How does supply chain collaboration affects business competitiveness of medium-sized food product retailers within Mahikeng, North-West province?'

\section{Research objectives}

The objectives of this study are expressed at three levels: primary, theoretical and empirical objectives.

\section{Primary objective}

The primary objective of this study was to explore whether business competitiveness of medium-sized food product retailers in Mahikeng, NW province is enhanced by SCM.

\section{Theoretical objective}

It was to review literature on competitive advantage theory, RBV theory, SCM, SCC, logistics management, 3PL, reverse logistics and related literature for this study using resources from leading SC journals publications, websites and the latest text books in SCM amongst others.

\section{Empirical objectives}

The empirical objectives of this study were to establish whether:

- Supply chain management enhances the business competitiveness of medium-sized food product retailers in Mahikeng, the NW province of South Africa;

- Supply chain collaboration enhances business competitiveness of medium-sized food product retailers in Mahikeng, NW province of South Africa.

\section{Research methodology and design}

This study used a qualitative research methodology and a descriptive research design was applied to descriptively explore and prove that SCM enhanced the business competitiveness of medium-sized food product retailers in Mahikeng. Maree (2013:51) stated that qualitative research is focussed on describing and understanding phenomena within their naturally occurring context with the intention of developing and understanding the meanings provided by the respondents. In addition, Creswell (2013) described:

$[Q]$ ualitative research as a process that begins with the assumptions and the use of theoretical frameworks that inform the research problem to address the meaning that individuals or groups have certain beliefs about a social or human problem. (p. 44)
Purposeful sampling was used to choose specific mediumsized food product retailers within Mahikeng town in the NW province, South Africa and this was based on their sizes and willingness to participate in this study. Maree (2013:79) described purposeful sampling as 'a case where participants are selected because of some specific characteristic that makes them holders of data needed for the study'. This technique was used because the study focused on the organisations that are in the business of selling food products.

The researcher approached owner/managers of mediumsized food product retailers to receive their permission to conduct this study and they offered to participate and confidentiality was assured to them. Units of analysis in this study were medium-sized food product retailers based in Mahikeng. Macaluso (2015) described a unit of analysis as 'a specifically identified organisation that the researcher seeks to study or research about'.

\section{Data collection and sample size}

Data were collected through face-to-face interviews with owner/managers of medium-sized food product stores in Mahikeng as they are directly involved in the running and management of the stores. An interview schedule with an open-end was used to gather as much information as possible from respondents in an attempt to assist the researcher to explore their opinions in how SCM contributes to their business competitiveness. The initial targeted sample size was 20 , but 15 interviews were conducted because the saturation point was reached. The main purpose of these interviews was explained to the participants prior to the interview date and the respondents were requested to sign the informed consent letter. The important points were recorded using both a field note book and an audio was recorded. The recorded data were transcribed, translated and coded to be prepared for analysis.

\section{Data analysis}

Data were analysed using thematic and content data analytic techniques with an aim to express the outcome of the study in a form of themes emanating from data analysis. A thematic data analysis seeks to identify the emerging themes and also identify links within themes (Vaismoradi, Turunen \& Bondas 2013), whereas Stemler (2001) describes content analysis as 'a systematic, replicable technique for compressing many words of text into fewer categories based on explicit rules of coding'. The outcome from data analysis was classified as major themes and minor themes and content analysis was used to establish the outcome of the study. There were six themes that emerged from the analysed data and these are: SC challenges, competitive advantage, relationship with suppliers, dealing with competitors, customer service and competitive advantage and benefits of using SC (See Table 1).

\section{Validity and reliability}

Validity of data was assured by comparing the transcribed data with the note book and the audio recorder to check 
TABLE 1: Main themes and sub-themes that emanated from thematic data analysis.

\begin{tabular}{ll}
\hline Main themes & Sub-themes \\
\hline Supply chain challenges & $\begin{array}{l}\text { Suppliers' location, transportation costs, late deliveries, } \\
\text { outsourced, breakdowns and rented warehouse space. }\end{array}$ \\
Competitive advantage & $\begin{array}{l}\text { Availability of stock, suppliers, discount, credit and } \\
\text { prices. }\end{array}$ \\
Relationship with suppliers & $\begin{array}{l}\text { Good relationships with suppliers, better prices and } \\
\text { offer of good deals and availability of stock. }\end{array}$ \\
Dealing with competitors & $\begin{array}{l}\text { Offer better customer service, lower prices, discounts, } \\
\text { promotions, availability of stock and increased } \\
\text { customer base. }\end{array}$ \\
Customer service and & $\begin{array}{l}\text { Good customer service, better prices, discounts, } \\
\text { promotion and reduced waiting time. }\end{array}$ \\
competitiveness & $\begin{array}{l}\text { Good relationships, collaboration, stock availability and } \\
\text { competitiveness. }\end{array}$ \\
\hline
\end{tabular}

convergence through triangulation. Carter et al. (2014:545) stated that triangulation in a qualitative research is perceived as 'a strategy to measure validity by checking similarities (convergence) of information from various sources'. Reliability in this study was realised through the determination whether the findings were congruent with what the study intended to achieve in relation to the instrument. Blanche, Durrheim and Painter (2012:92) stated that 'reliability refers to a degree to which the results are repeatable'.

\section{Ethical consideration}

Arifin (2018) indicated that:

[E]thical considerations in a qualitative study have a specific significance because of the in-depth nature of its study process. Also, the concern of ethical issues in a qualitative study becomes more noticeable when conducting face-to-face interviews with vulnerable respondents. (p. 30)

In this study, ethical considerations of research ethics were followed throughout the research process and this study pursued the process of getting ethical clearance certificate from the research scientific committee of the faculty. Prior to the interviews, the researcher asked for permission from the participants to participate in the study and they were also requested to sign an informed consent.

Anonymity and confidentiality were guaranteed stating that the details of participants and the organisation will not be disclosed as this was for the research purpose only.

\section{Results and discussion}

The results that emanated from thematic data analysis in this study comprised of six main themes and these are: SC challenges, competitive advantage, relationship with suppliers, dealing with competitors, customer service and competitiveness and benefits from SC. These themes were supported by sub-themes as shown in Table 1. The empirical objectives of this study were established as they seem to have featured outstandingly in themes. All the feedback from the data analysis process was approached by classifying the results into themes that were consistent with the questions that the respondents were asked throughout the interviewing process. The inductive coding approach known as open coding was used to determine the themes from the data and the themes were then classified into major themes and subthemes as shown in Table 1.

\section{Achievement of objectives}

The research objectives of this study were expressed at three levels: primary, theoretical and empirical objectives. Themes emanating from data analysis as shown in Table 1 resonated well with both primary and empirical objectives set for the study and direct comments from respondents.

\section{Primary objective}

The primary objective of this study was to explore whether SCM enhances business competitiveness of medium-sized food product retailers in Mahikeng. This was achieved by the realisation of both theoretical and empirical objectives of this study.

\section{Theoretical objective}

This objective was achieved by reviewing literature on theories at which this study was underpinned, reviewing literature on SC, SCM, logistics management, 3PL, reverse logistics and other SC-related concepts.

\section{Empirical objectives}

The two empirical objectives of this study were achieved as corroborated by themes and the evidence from the respondents stated as follows:

Empirical objective 1: Supply chain management enhances the business competitiveness of medium-sized food product retailers in Mahikeng, the North-West province of South Africa. (Achieved)

It has emerged from main themes and sub-themes that SCM was really important, enhancing the business competitiveness of the medium-sized food product retailers in Mahikeng. Predominantly, the respondents in this study highlighted that despite some of the SC challenges they face, they have benefited positively by adopting SC. It was found out that suppliers contributed a lot to the improvement of their competitive advantage by offering better deals such as getting lower prices and this translated in retailers offering their customers good customer service by making sure that they have stock available, offering their customers lower prices by beating the prices of their competitors. This empirical objective was achieved through three main themes that emerged from data analysis as discussed in the following subsection supported by some feedback from respondents.

Competitive advantage: It is shown that a competitive advantage of medium-sized food products retailers in Mahikeng is enhanced by some of the drivers such as having the stock available, getting better deals from suppliers and offering lower prices to customers. These are some of the factors contributing to their business competitiveness. The 
following is one of the feedbacks from the respondents:

'Our strong relationship with suppliers assist us to be more competitive by having stock readily available at better prices and offering us discount and we also allow us to buy on credit. With better prices that we get from our supplier we are also able to reduce our costs and pass on savings to our customers.' (Respondent 05, Male, Owner/Manager, 35 years of experience)

Dealing with competitors: This theme has shown that most of the medium-sized food products retailers deal with their competitors by offering their customers good service and beating their prices by matching and selling at lower prices. Some indicated that they differentiate themselves by keeping their customers happy by not having them to queue too long at pay-points. This is supported by some feedbacks from respondents.

\begin{abstract}
'As you may be aware, price competition is one of the competitive measures in and any business. To be more competitive than our competitors we sell at lower price to our customers but not compromising our profitability and sometimes we sell at similar prices as our competitors. We also have stock always available to avoid losing customers to our competitors due to stock unavailability and we offer better service to our customers so feel happy.' (Respondent 12, Female, Manager, 20 years of experience)
\end{abstract}

More of a similar response is expressed as follows:

\begin{abstract}
'There are two important things that make us more competitive than our competitors. Firstly, we make sure we have stock available at all times as when customers demand and secondly we either offer lower prices and discount or we sell at the same prices as our competitors.' (Respondent 14, Male, Owner/ Manager, 15 years of experience)
\end{abstract}

Customer service and competitiveness: Predominantly, it was revealed that better customer service plays a positive role in the business competitiveness. Respondents highlighted that through a good relationship with their SC partners, they have been successful improving their competitiveness as they offer their customers good service. The following are some of the feedbacks:

'Very important because without customers you cannot trade. Our customers form part of the success of our business. Through a better customer service and better prices we offer our customers who have benefited us to remain competitive because our customers have become our word of mouth advertisers and this brought us more customers.' (Respondent 02, Male, Owner/ Manager, 6 years of experience)

The other respondents had this view:

'Our customers form part of our business and if we do not keep them happy they go to the competitors, so we make sure they are always happy. With a good relationship with our customers we are more competitive than our competitors. The more customers you have the more competitive you become. Our customers contribute by a word of mouth and we get new customers as we have noticed that our customer base has increased and also old customer are coming back because they meet their requirements. Our customers play a great role in our business competitiveness.' (Respondent 07, Female, Manager, 10 years of experience)
Empirical objective 2: Supply chain collaboration enhances business competitiveness of medium-sized food product retailers in Mahikeng, the North-West province of South Africa. (Achieved)

This empirical objective was established to prove that SCC drives business competitiveness of medium-sized food products retailers in Mahikeng. This was achieved where respondents asked about the adoption of SC and the supplier/customer relationship. Predominantly, it was revealed that the retailers have good working relationships with their SC partner. The following are some of the feedbacks from respondents:

'We sell perishable food products. The food products chain has benefited us in that we always get our products delivered in good temperature and this made us to sell fresh products to our customers due to the best refrigeration logistics collaborated arrangement we have with our suppliers. Also good working relationship with other supply chain partners has assisted us in being more competitive than our competitors.' (Respondent 04, Male, Owner/Manager, 20 years of experience)

'Food products retail chain is a complicated supply chain because we have many suppliers of different product lines we sell. With good working relationships with our supplier we managed to offer the best service to our customers and outperform our competitors and was realised in an improved business performance. We again make use of our third party logistics transport service provider to have our orders delivered to our store with reduced cost. The main objective of supply chain is to ensure the products are available as when the customer want them and we were able to have stock available on our shelves through our best partners. The other benefit is that we order from our suppliers through our distribution centre (DCs) and this saves us time and money and also collaborate very well with them and I must say we have been more competitive by collaborating.' (Respondent 15, Male, Owner/ Manager, 12 years of experience)

\section{Conclusion}

The general objective of this study was to prove that SCM enhances the business competitiveness of medium-sized food product retailers in Mahikeng. The study applied the competitive advantage and RBV theories. The study was carried out using a descriptive qualitative research design, where 15 face-to-face semi-structured interviews were conducted with owner/managers and this is where a saturation point was reached. The data that came out from interviews were transcribed, coded and analysed using the Atlas.ti computer program. Thematic data analysis was followed to analyse data from which six main themes emerged and these are: SC challenges, competitive advantage, relationship with suppliers, dealing with competitors, customer service and competitiveness and benefits from SC. Both primary and empirical objectives were achieved as the main finding of this study showed that business competitiveness of medium-sized food products retailers in Mahikeng is enhanced through SCM.

Empirical objective one which sought to explore whether SCM enhances the business competitiveness of medium- 
sized food products retailers in Mahikeng, NW province of South Africa, it can be concluded that the adoption and application of SCM by medium-sized food products retailers in Mahikeng enhanced their competitiveness through supplier-customer relationships. Therefore, at this point, the research question one formulated as 'How does SCM affects the business competitiveness of medium-sized food products retailers with in Mahikeng, NW province?' can be answered.

Empirical objective two which sought to explore whether SCC enhances business competitiveness of medium-sized food products retailers in Mahikeng, NW province of South Africa, it can be concluded that collaboration in a SC through good working relationships enhances the business competitiveness of medium-sized food products retailers in Mahikeng, NW province. Therefore, research question two formulated as 'How does supply chain collaboration affects business competitiveness of medium-sized food products retailers with in Mahikeng, NW province?' can be answered.

Therefore, the finding of this study revealed that business competitiveness of medium-sized food products retailers is enhanced through SC as reflected in the achievement of empirical objectives and research questions answered.

\section{Theoretical and practical implications}

This study revealed that SCM, SCC and good supplier/ customer relationship enhance business competitiveness of medium-sized food product retailers in Mahikeng. Theoretically, the study successfully attempted to apply the competitive advantage and resource-based theories in the field of medium-sized food product retail business in Mahikeng. Therefore, this study submits that these theories can be used together to explain the impact of SC performance, SCC and SC relationships on business competitive advantage of medium-sized food product retailers in Mahikeng.

Practical implication of this study will benefit all the mediumsized food product retailers in Mahikeng by having a pure understanding of important SC initiatives that contribute to the business competitiveness and sustainability. This study assists the owners/managers for medium-sized food products retailers in Mahikeng to have the best understanding of the benefits adopting SCM.

\section{Contribution of the study}

The finding of this study revealed that the adoption and application of SCM enhance the competitiveness of mediumsized food products retailers in Mahikeng, NW province. Firstly, this study contributed to the body of knowledge as a gap was identified that there was no empirical evidence that could be traced explaining SCM of Mahikeng medium-sized food products retailers; hence, this current study submitted to discover ways in closing this gap. Secondly, this study equipped the owner/managers and employees with an insight about how important is SCM to the business competitiveness and sustainability. Lastly, the study also offered clarity on the influence of SC initiatives such as SCC and SC relationships on the competitiveness of the business. With a complete understanding of these initiatives, owner/ managers will be able to modify their management practices to cost-effectively (profitably) run their businesses. In this study, cost-effectively (profitably) means providing goods and services at the lowest costs.

\section{Limitations of the study}

This study focused only on medium-sized food product retailers who are based in Mahikeng and did not include those who are from other places in the NW province and also those from other provinces in South Africa. The study further excluded large food product retailers, smaller food product retailers such as spaza shops and distributors. The empirical data collection included the owner/managers of the stores with the exclusion of the employees.

\section{Recommendations and implication of future research}

Most of the recommendations of this study are based on extra information gathered from the respondents regarding their challenges. The study recommends that owners/ managers of the medium-sized food product retailers have warehouse or distribution centres located in Mahikeng, so they save on transport costs as their suppliers are based in Mahikeng. Medium-sized food products retailers should assess the performance of their 3PL (transport service providers) before considering to use their services. The study recommends that similar studies should be conducted in other places in the NW province and also in other provinces in South Africa and, lastly the same study should be undertaken in other types of retailers besides medium-sized food products retailers.

\section{Acknowledgements}

The authors would like to acknowledge NWU for funding this study as well as the reviewers of the manuscript draft.

\section{Competing interests}

The authors declare that they have no financial or personal relationships which may have inappropriately influenced them in writing this article.

\section{Authors' contributions}

This article is based on the M.Com dissertation of K.F.M. and therefore K.F.M. was the main researcher. K.W.M. helped as the co-supervisor in conceptualisation of this study.

\section{Ethical considerations}

This research study was approved by Economic and Management Sciences Research Committee at the North- 
West University. Prior to the interviews, the researcher asked for permission from the participants to participate in the study and they were also requested to sign an informed consent. Anonymity and confidentiality were guaranteed stating that the details of participants and the organisation will not be disclosed as this was for research purpose only. NWU-01451-19-A4.

\section{Funding information}

This study received no funding from agencies from public, commercial or non-profit organisations.

\section{Data availability}

Data sharing is not applicable to this article as no new data were created or analysed in this study.

\section{Disclaimer}

The ideas and opinions reflected in this article are those of the authors for research purposes only.

\section{References}

Adeniran, T.V. \& Johnston, K.A., 2012, 'Investigating the dynamic capabilities and competitive advantage of South African SMEs', African Journal of Business Management 6(11), 4088-4099. https://doi.org/10.5897/AJBM11.1673

Ambe, I.M., 2010, 'Agile supply chain. Strategy for competitive advantage', Journal of Global Strategic Management 4(1), 5-17. https://doi.org/10.20460/JGSM.2010415835

Apaiah, K.R., Linnemann, A.R. \& Kooi, H.J., 2011, 'A tool to study the sustainability of food supply chains', Journal of Food Research International 39(1), 1-51. https:// doi.org/10.1016/j.foodres.2005.04.006

APICS (American Production and Inventory Control Society), 2013, The essential supply chain reference, APICS dictionary, APICS, Chicago, IL.

Arifin, S.R.M., 2018, 'Ethical considerations in qualitative study', International Journal of Care Scholars 1(2), 30-33.

Badenhorst-Weiss, J., Colliers, J.O. \& Eicker, T., 2014, 'Unique market offering by formal independent retail and wholesale small businesses in Soweto township', South African Problems and Perspectives in Management 12(4), 366-376.

Barney, J., Wright, M. \& Ketchen, D.J., 2001, 'The resource-based view of the firm: Ten years after 1991', Journal of Management 27(6), 625-641. https://doi. org/10.1177/014920630102700601

Biz Community, 2020, Distribution companies South Africa, viewed 01 May 2021, from https://www.bizcommunity.com/Companies/196/553.html.

Blanche, M.T., Durrheim, K. \& Painter, D., 2012, Research in practice: Applied methods for the social sciences, 2nd edn., University of Cape Town (UCT) Press, Cape Town.

Boyce, W.S., Mano, H. \& Kent, J.L., 2016, 'The influence of collaboration in procurement relationships', International Journal of Managing Value and Supply Chains 7(3), 1-18. https://doi.org/10.5121/ijmvsc.2016.7301

Bridoux, F., 2006, Resource-based approach to performance and competition: An overview of the connections between resources and competition. Institu d'Administration et de Gestion, Université catholique de Louvain, Belgium.

Carter, N., Bryant-Lukosius, D., DiCenso, A., Blythe, J. \& Neville, A.J., 2014, 'The use of triangulation in qualitative research', Oncology Nursing Forum 41(5), 545-547. https://doi.org/10.1188/14.ONF.545-547

Christopher, M., 2011, Logistics and supply chain management, 4th edn., Financial Times Publishing-Pearson Education Limited, London.

Christopher, M., 2016, Logistics and supply chain management, 5th edn., Financial Times Publishing-Pearson Education Limited, London.

Creswell, J.W., 2013, Qualitative inquiry \& research design: Choosing among five approaches, 4th edn., Sage, Thousand Oaks, CA.

CSCMP (Council of Supply Chain Management Professionals), 2012, Supply chain management definitions, viewed 15 January 2021, from https://cscmp.org/ supply-chain-management-definations.

Das Nair, R. \& Chisoro, S., 2015, The expansion of regional supermarket chains: Changing models of retailing and the implications for local supplier capabilities in South Africa, Botswana, Zambia, and Zimbabwe, United Nations University World Institute for Development Economics Research. WIDER Paper 2015/114, viewed 10 April 2021, from https://www.researchgate.net/publication/303984408_Theexpansion of regional_supermarket_chains_Changing_models_of_retailing and_implications_for_local_supplier_capabilities_in_South_Africa_Botswana_ Zambia_and_Zimbabwe.
Du Toit, D.C., Ramonyai, M.D., Lubbe, P.A. \& Ntushelo, V., 2011, Food security, pp. 12-36, vol. 2, Department of Agriculture, Forestry and Fisheries, Pretoria.

Fuzile, L., 2015, Public sector supply chain management review, Treasury, Pretoria.

Goldenberg, B., 2010, 'What is CRM? What is an e-consumer? Why you need them now in proceedings $\mathrm{DCl}^{\prime}$, in customer relationship management conference, pp. 27-29, June 23, Boston, MA.

Harrison, A., Van Hoek, R. \& Skipworth, H., 2014, Logistics management and strategy: Competing through the supply chain, 5th edn., Pearson Education Limited, London.

Hatten, T.S., 2012, Principles of small business management, 5th edn., South-Western Cengage, Florence.

Hoffman, K., 2014, 'Non communicable diseases in South Africa. A challenge to economic development', South Africa Medical Journal 104(10), 22-56. https:// doi.org/10.7196/SAMJ.8727

Hsiao, H.I., Van der Vorst, J.G., Kemp, R.G.M. \& Omta, S.W.F., 2010, ‘Developing a decision-making framework for levels of logistics outsourcing in food supply chain networks', International Journal of Physical Distribution \& Logistics Management 40(5), 395-414. https://doi.org/10.1108/09600031011052840

Industry Today, 2020, FMCGs get off shelf, viewed 02 May 2021, from https:// industrytoday.com/fmcgs-get-off-the-shelf/.

Jooste, C.J., Strydom, J.W., Berndt, A. \& Du Plessis, P.J., 2012, Applied strategic marketing, 4th edn., Pearson, Cape Town.

Jurevicius, O., 2013, Resource based view, viewed 27 February 2021, from https:// strategicmanagement.com/topics/resource-based-view.html.

Kolinska, K., 2016, Logistics management: Modern developments trend, Poznan School of Logistics Press, Poland.

KPMG (Klynveld Peat Marwick Goerdeler) Sector Report, 2014, Fast-moving consumer goods in Africa, viewed from https://www.tralac.org/images/docs/6113/fasmoving-consumer-goods-in-africa.pdf.

Lambert, D.M., 2014, Supply chain management: Processes, partnerships, performance, 4th edn., Supply Chain Management Institute, Florida.

Lambert, D.M \& Schwieterman, M.A. 2012. Supplier relationship management as a macro business process. Supply Chain Management. An International Journal, 17(3), 337-352.

Macaluso, S., 2015, Organizing data: Unit of analysis and levels measurement, viewed 15 March 2021, from www.youtube.com/watch?v=fc62JXU.

Maree, K., 2013, First step in research, rev. edn., Van Schaik, Pretoria.

Mathu, K. \& Phetla, S., 2018, 'Supply chain collaboration and integration enhance the response of fast-moving consumer goods manufacturers and retailers to
customer's requirements', South African Journal of Business Management 49(1), a192. https://doi.org/10.4102/sajbm.v49i1.192

Mathuramaytha, C., 2011, 'Supply chain collaboration: What's an outcome? A theoretical model', in International conference on financial management and economics, International Proceedings of Economics Development and Research (IPEDR), p. 11, International Association of Computer Science and Information Technology (IACSIT) Press, Singapore.

Pienaar, W.J. \& Vogt, J.J., 2016, Business logistics management: A value chain perspective, 5th edn., Oxford University Press, Cape Town.

Pinder, S., Walsh, P., Orndorff, M., Milton, E. \& Trescott, 2017, The future of food: New realities for the industry: Part of Accenture strategy, FMI the voice of food retail, viewed 12 February 2020, from www.accenture.com/strategy.

PMA (Product Market Association) Research Report, 2017, Competition increases in South African retail environment, viewed 15 February 2020, from https://www. pma.com/search\#f:@topicfacet=[supply\%chain\%20\%standards.

Porter, M.E., 1985, Competitive advantage: Creating and sustaining superior performance, The Free Press, New York, NY.

Porter, M.E., 2008, Competitive advantage: Creating and sustaining superior performance, The Free Press, New York, NY.

PWC (Price Waterhouse Coopers), 2016, Prospects in the retail and consumer goods sector in ten sub-Saharan countries, viewed 28 May 2021, from www.pwc.co.za/ retailer-and-consumer.

Rothaermel, F.T., 2012, Strategic management: Concepts and cases, McGraw-Hill/ Irwin, New York, NY.

Scarborough, N.M., 2011, Essentials of entrepreneurship and small business management, 6th edn., Pearson Prentice Hall, Upper Saddle River, NJ.

Slack, N., Brandon-Jones, A., Johnston, R., Singh, H. \& Phihlela, K., 2017, Operations management: Global and Southern African perspectives, 3rd edn., Pearsons Education, Cape Town

Stemler, S., 2001, An overview of content analysis: Practical assessment, research and evaluation, vol. 7, no. 17, viewed 09 April 2020, from http://pareonline.net/getvn. asp? $y=7 \& n=17$.

Supply Chain Council (SCC), 2016, Technology as an enabler for strategic business development in the retail sector, viewed 08 July 2021, from http://www.scc.com/ wp-content/uploads/2016/07/Technology-as-an-enabler-for-strategic-businessdevelopment.pdf.

Szuster, M., 2010, 'Outsourcing of transport service: Perspective of manufacturers', Total Logistics Management (3), 87-98.

Thompson, J. \& Martin, F., 2010, Strategic management: Awareness and change, 6th edn., South-Western Cengage, Florence. 
Udeh, D.O. \& Karaduman, I., 2015, 'The impact of supply chain in the warehouse management systems of Turkish Automotive Industry', International Journal of Economics, Commerce and Management 3(5), 410-423.

Vaismoradi, M., Turunen, H. \& Bondas, T., 2013, 'Content analysis and thematic analysis: Implications for conducting qualitative descriptive study', Nursing and Health Sciences 15(3), 398-405. https://doi.org/10.1111/nhs.12048
W\&R SETA (Wholesale and Retail Sector Education and Training Authority), 2011, Independent food retailers in the Republic of South Africa: Can they ensure Independent food retailers in the Republic of South Africa: Can they ensure
sustainability in an evolving retail landscape? Imitha Rays of the Sun, Durban.

Waugh, B. \& Luke, R., 2011, 'Logistics outsourcing by manufacturers in South Africa', Journal of Transport and Supply Chain Management 5(1), 337-360. https://doi. org/10.4102/jtscm.v5i1.81 